\title{
Analysis of The Level of Passenger Satisfaction With Services And Transport Facilities-Based Integration in Jakarta
}

\author{
Andri Irfan Rifai and Fachrul Arifin \\ Faculty of Engineering, University of Mercu Buana Jakarta, Indonesia \\ andrirfan@yahoo.com, farifin10@gmail.com
}

\begin{abstract}
Rapid development in major cities in the world, especially in developing countries resulted in increased community activities. This has an impact on the community's increased traffic, causing a variety of impacts ranging from congestion, increased air pollution, wasted fuel, and reduced levels of comfort in traffic. The integration of public transport is one of the ways used by the Jakarta provincial government to address the level of congestion is getting worse. One of the areas in Jakarta that have been designated as regional transport integration is Dukuh Atas Region. Improved integration of services and public transport facilities can increase the interest of society to move from using private transport be using public transportation. This is the underlying researchers to conduct research on the assessment of the level of passenger satisfaction and service performance-based integration of transport facilities in Jakarta (Region case study Integration Dukuh Atas) and know the attributes that affect passenger satisfaction. Conclusions from the results of the study indicate that passengers are satisfied with the level of service and transportation integration facilities in the Dukuh Atas Region with CSI score 70,46\%. But the need for some improvement of the performance attributes that are getting a low value, such as the integration between public transport schedules and timeliness of arrival and departure transportation.
\end{abstract}

Keywords: Public Transport, Integration, Satisfaction, SPSS

\section{Introduction}

Rapid development in major cities in the world, especially in developing countries resulted in increased community activities. This increase is also directly proportional to the needs of the community for the traffic thus causing traffic jams that result in travel time becomes longer [1]. Besides congestion also result in increased air pollution, wasted fuel, and reduced levels of comfort in traffic.

In Indonesia, especially Jabodetabek jams occur almost every day, especially on weekdays. Many communities still rely on private vehicles in traveling. Based on the Central Bureau of Statistics (BPS), the number of vehicles in Jakarta increased to 9\% annually. It is not offset by the construction of roads in Jakarta, which is only $0.01 \%$ per year. The harm caused is quite large. Of increased air pollution, to the economic losses. According to data from Bappenas, economic losses due to congestion in Jakarta based on data for 2013 amounting to Rp. 63 billion per year and in 2019 close to Rp. 100 trillion.

In the face of the Jakarta provincial government together with related agencies working to provide transportation that is safe, convenient, efficient and effective. Starting from maximizing KRL, improving the public transport system based highways such as transportation (public transportation) and also Transjakarta to build a Mass Rapid Transit (MRT) and Light Rail Transit (LRT). That then all will be integrated to create an efficient transport system. Because the integration of public transport is the most rational solution to overcome the problems of urban transport [2].

With the integration of public transport systems are good, people are expected to switch from private vehicles and choose to use public transport as a first choice in traveling because it offers a public transport system which is connected to each other so that the journey will be easier and smoother [3]. The researchers are interested to analyze the level of passenger satisfaction with services and transport facilities based in Jakarta for the future integration of services and public transport facilities in Jakarta can be again.

This study aims to determine how much the level of passenger satisfaction with the service and the transport facilities-based integration in Jakarta and to identify service quality attributes that are considered most important to the performance of services and transport facilities-based integration in Jakarta. 


\section{Methodology}

The research data was obtained from the collection of primary data and secondary data. Primary data is the result of questionnaires to passengers in the area of transport integration Dukuh Atas. Secondary data were obtained from literature and previous research.

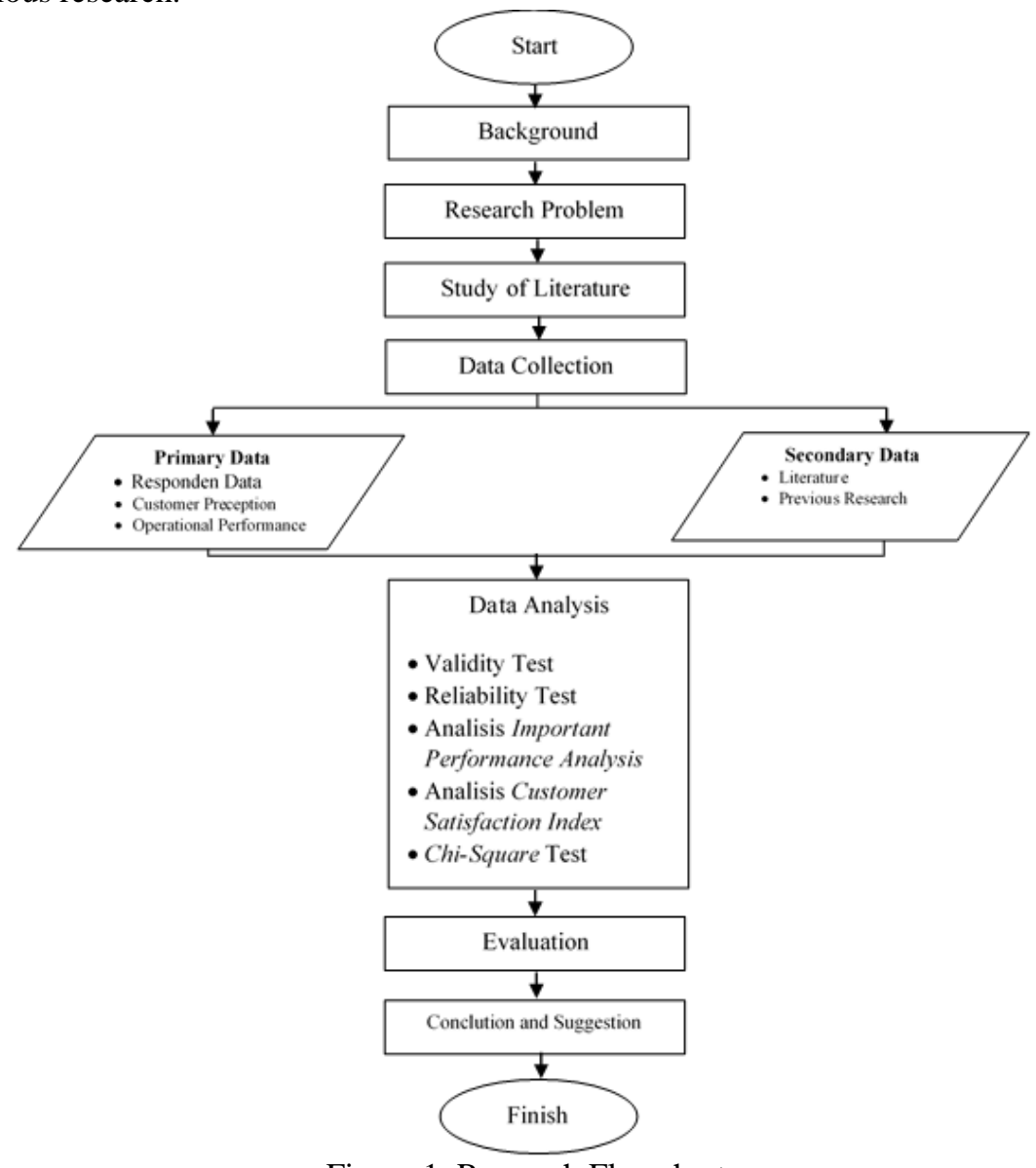

Figure 1. Research Flowchart

Source: Data in research, 2020

Data were analyzed using the following method:

\subsection{Importance-Performance Analysis (IPA)}

IPA analysis is used to measure the relationship between consumer perceptions and priorities for improving the quality of products/services also known as the quadrant analysis [4]. IPA combines measurements of factor's importance and satisfaction level in 2-dimensional graphics ease of explanation data. This concordance rate determines the priority order of service affecting passenger satisfaction.

\subsection{Customer Satisfaction Index (CSI)}

CSI analysis is used to know the passenger satisfaction index of the performance of services in the area of integration Dukuh Atas. CSI will calculate the index per passenger satisfaction and overall service attributes.

The measures used to express the satisfaction of passengers are as follows
a. $\quad 0.81$ to $100=$ Extremely Satisfied
b. From 0.66 to $0.80=$ Satisfied
c. $\quad 0.51$ to $0.65=$ Quite Satisfied
d. $\quad 0.35$ to $0.5=$ Less Satisfied
e. $\quad 0.00$ to $0.34=$ Extremely Dissatisfied

\subsection{Chi-Square Test}

Chi-Square test is a non-parametric statistical test that can be applied to the test data nominal and nominal categorical. A chi-square test is used to examine the relationship between variables. 


\section{Results and Discussion}

\subsection{Test Validity}

The validity of test results to the level of satisfaction and the interests of all the variables declared invalid because $r$ count $>$ of $r$ table.

a. Importance

Table 1. Validity Test (Importance)

\begin{tabular}{|c|c|c|c|c|}
\hline \multicolumn{5}{|c|}{ Item-Total Statistics } \\
\hline & $\begin{array}{l}\text { Scale Mean if } \\
\text { Item Deleted }\end{array}$ & $\begin{array}{c}\text { Scale } \\
\text { Variance if } \\
\text { Item Deleted }\end{array}$ & $\begin{array}{l}\text { Corrected } \\
\text { Item-Total } \\
\text { Correlation }\end{array}$ & $\begin{array}{c}\text { Cronbach's } \\
\text { Alpha if Item } \\
\text { Deleted }\end{array}$ \\
\hline $\mathrm{X} 1$ & 100.5143 & 340.862 & 0.806 & 0.977 \\
\hline $\mathrm{X} 2$ & 100.6143 & 347.690 & 0.670 & 0.978 \\
\hline $\mathrm{X} 3$ & 100.5429 & 345.208 & 0.656 & 0.978 \\
\hline $\mathrm{X} 4$ & 100.6714 & 341.963 & 0.767 & 0.978 \\
\hline $\mathrm{X} 5$ & 100.5429 & 340.745 & 0.815 & 0.977 \\
\hline X6 & 100.7143 & 341.337 & 0.800 & 0.977 \\
\hline $\mathrm{X} 7$ & 100.6429 & 342.668 & 0.811 & 0.977 \\
\hline $\mathrm{X} 8$ & 100.4714 & 346.688 & 0.756 & 0.978 \\
\hline X9 & 100.6000 & 340.678 & 0.829 & 0.977 \\
\hline $\mathrm{X} 10$ & 100.8714 & 342.201 & 0.688 & 0.978 \\
\hline $\mathrm{X} 11$ & 100.7857 & 342.171 & 0.735 & 0.978 \\
\hline $\mathrm{X} 12$ & 100.8286 & 340.550 & 0.800 & 0.977 \\
\hline $\mathrm{X} 13$ & 100.5143 & 340.543 & 0.788 & 0.978 \\
\hline $\mathrm{X} 14$ & 100.7143 & 336.062 & 0.847 & 0.977 \\
\hline $\mathrm{X} 15$ & 100.6000 & 338.852 & 0.827 & 0.977 \\
\hline $\mathrm{X} 16$ & 100.5857 & 340.130 & 0.875 & 0.977 \\
\hline $\mathrm{X} 17$ & 100.5571 & 342.453 & 0.827 & 0.977 \\
\hline $\mathrm{X} 18$ & 100.6857 & 338.798 & 0.838 & 0.977 \\
\hline X19 & 100.7000 & 338.387 & 0.828 & 0.977 \\
\hline $\mathrm{X} 20$ & 100.8857 & 338.248 & 0.739 & 0.978 \\
\hline $\mathrm{X} 21$ & 100.6571 & 339.417 & 0.825 & 0.977 \\
\hline $\mathrm{X} 22$ & 100.7143 & 340.381 & 0.845 & 0.977 \\
\hline $\mathrm{X} 23$ & 100.7429 & 338.020 & 0.839 & 0.977 \\
\hline X24 & 100.7143 & 336.990 & 0.873 & 0.977 \\
\hline $\mathrm{X} 25$ & 100.7000 & 338.271 & 0.806 & 0.977 \\
\hline
\end{tabular}

Source: Data in research, 2020 
b. Level of Satisfaction

Table 2. Validity Test (Satisfaction)

\begin{tabular}{|c|c|c|c|c|}
\hline \multicolumn{5}{|c|}{ Item-Total Statistics } \\
\hline & $\begin{array}{l}\text { Scale Mean if } \\
\text { Item Deleted }\end{array}$ & $\begin{array}{c}\text { Scale } \\
\text { Variance if } \\
\text { Item Deleted }\end{array}$ & $\begin{array}{c}\text { Corrected } \\
\text { Item-Total } \\
\text { Correlation }\end{array}$ & $\begin{array}{l}\text { Cronbach's } \\
\text { Alpha if Item } \\
\text { Deleted }\end{array}$ \\
\hline $\mathrm{X} 1$ & 84.6571 & 260.258 & 0.691 & 0.962 \\
\hline $\mathrm{X} 2$ & 84.7857 & 264.171 & 0.581 & 0.963 \\
\hline X3 & 84.2286 & 263.947 & 0.650 & 0.963 \\
\hline $\mathrm{X} 4$ & 84.6571 & 259.794 & 0.749 & 0.962 \\
\hline $\mathrm{X} 5$ & 84.5429 & 258.542 & 0.748 & 0.962 \\
\hline X6 & 84.5429 & 262.716 & 0.714 & 0.962 \\
\hline $\mathrm{X} 7$ & 84.6429 & 262.146 & 0.662 & 0.962 \\
\hline $\mathrm{X} 8$ & 84.4857 & 261.616 & 0.669 & 0.962 \\
\hline X9 & 84.5429 & 261.643 & 0.707 & 0.962 \\
\hline $\mathrm{X} 10$ & 84.5714 & 256.364 & 0.746 & 0.962 \\
\hline $\mathrm{X} 11$ & 84.4857 & 259.732 & 0.736 & 0.962 \\
\hline $\mathrm{X} 12$ & 84.5429 & 259.875 & 0.743 & 0.962 \\
\hline $\mathrm{X} 13$ & 84.5429 & 260.976 & 0.675 & 0.962 \\
\hline X14 & 84.6286 & 259.338 & 0.721 & 0.962 \\
\hline $\mathrm{X} 15$ & 84.8000 & 256.452 & 0.741 & 0.962 \\
\hline $\mathrm{X} 16$ & 84.5286 & 259.499 & 0.647 & 0.963 \\
\hline $\mathrm{X} 17$ & 84.2571 & 257.759 & 0.754 & 0.962 \\
\hline $\mathrm{X} 18$ & 84.5000 & 262.399 & 0.640 & 0.963 \\
\hline X19 & 84.4429 & 259.671 & 0.743 & 0.962 \\
\hline $\mathrm{X} 20$ & 84.5000 & 263.500 & 0.589 & 0.963 \\
\hline $\mathrm{X} 21$ & 84.5143 & 257.210 & 0.755 & 0.962 \\
\hline $\mathrm{X} 22$ & 84.5429 & 258.947 & 0.777 & 0.961 \\
\hline $\mathrm{X} 23$ & 84.6143 & 258.820 & 0.738 & 0.962 \\
\hline $\mathrm{X} 24$ & 84.5286 & 257.760 & 0.724 & 0.962 \\
\hline $\mathrm{X} 25$ & 84.6286 & 257.541 & 0.710 & 0.962 \\
\hline
\end{tabular}

Source: Data in research, 2020 


\subsection{Test Reliability}

\section{a. Importance}

Table 3. Reliability Test (Importance)

\begin{tabular}{|c|c|}
\hline \multicolumn{2}{|c|}{ Reliability Statistics } \\
\hline Cronbach's Alpha & $\mathrm{N}$ of Items \\
\hline 0978 & 25 \\
\hline
\end{tabular}

b. level of Satisfaction

Table 4. Reliability Test (Satisfaction)

\begin{tabular}{cc}
\hline \multicolumn{2}{c}{ Reliability Statistics } \\
\hline Cronbach's Alpha & N of Items \\
\hline 0964 & 25 \\
\hline \multicolumn{2}{c}{ Source: Data in research, 2020 }
\end{tabular}

Source: Data in research, 2020

The validity of test results and the satisfaction level of importance can be summed data obtained otherwise reliable because it has a value of Cronbach's Alpha> of 0.6

3.4 Importance Performance Analysis

The results of IPA analysis of the level of service performance and the importance of public transport users in the area of integration Dukuh Atas, generating incoming service attributes in quadrant I-IV.

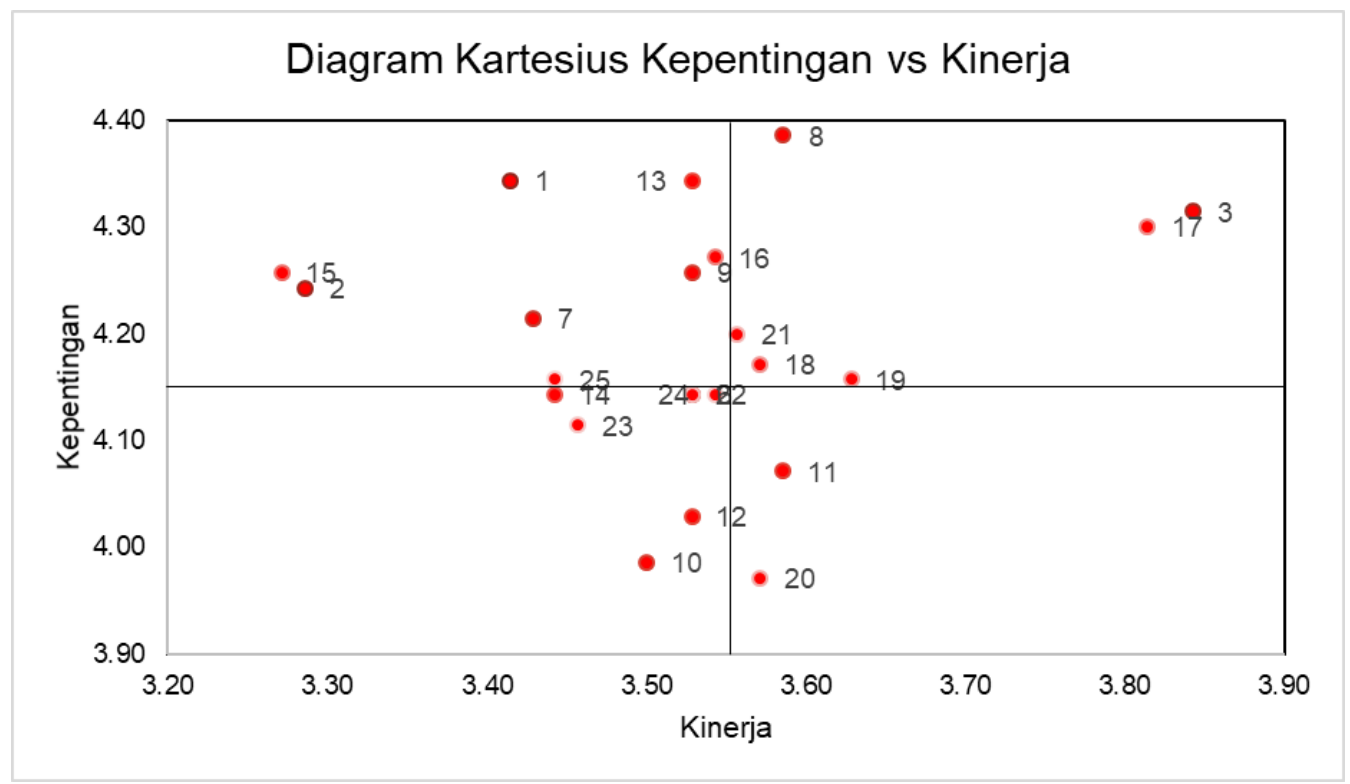

Figure 2. Diagram Cartesian Importance Performance Analysis

Source: Data in research, 2020

Figure 2 shows each incoming service attributes in quadrant I-IV which can be explained as follows:

1. Quadrant I (Priority)

Service attributes that go in this quadrant are: 
a. The availability of information related to public transportation schedules are available (1)

b. The integration of public transport schedules (2)

c. The ability to provide the best services (4)

d. The ease in obtaining clear information (5)

e. The ability of officers in response to complaints of passengers (7)

f. Responsiveness of officers in dealing with emergency situations (9)

g. Security at the time of transfer between public transport (13)

h. The accuracy of arrival and departure of transport (15)

i. The integration between the rates of public transport (16)

j. The conditions and the feasibility of switching between access to public transport (25)

2. Quadrant II (Preserve Achievement)

Service attributes that go in this quadrant are:
a. Ease of ticket purchase public transport modes (3)
b. The ability of officers in directing passengers to the destination (8)
c. Integration means of payment for a variety of transportation (17)
d. Ease of reaching public transportation (18)
e. Ease of getting information transport services (19)
f. Availability of access to transfer between public transport (21)

3. Quadrant III (Low Priority)

Service attributes that go in this quadrant are:

a. The speed and accuracy officers in providing the required passenger information (6)

b. Free access to information via applications (10)

c. The hospitality and courtesy officers in serving the passenger (12)

d. Leisure at the time of transfer between public transport (14)

e. The conditions and the feasibility of switching between access to public transport (22)

f. The availability of tools for service informs trips (23)

g. Cleanliness displacement access in public transport (24)

4. Quadrant IV (Redundant)

Service attributes that go in this quadrant are:

a. The ability of officers in serving the customer (11)

b. The proximity of the destination location with transport services (20)

\subsection{Customer Satisfaction Index}

Table 5. Result Customer Satisfaction Index

\begin{tabular}{|c|c|c|c|c|}
\hline Attribute & Interest Score & $\begin{array}{c}\text { Performance } \\
\text { Score }\end{array}$ & $\begin{array}{c}\text { Weight } \\
\text { Factor }\end{array}$ & $\begin{array}{c}\text { Weight } \\
\text { Score }\end{array}$ \\
\hline 1 & 4.34 & 3.41 & 0.0414 & 0.1414 \\
\hline 2 & 4.24 & 3.29 & 0.0405 & 0.1330 \\
\hline 3 & 4.31 & 3.84 & 0.0411 & 0.1581 \\
\hline 4 & 4.19 & 3.41 & 0.0399 & 0.1363 \\
\hline 5 & 4.31 & 3.53 & 0.0411 & 0.1452 \\
\hline 6 & 4.14 & 3.53 & 0.0395 & 0.1394 \\
\hline 7 & 4.21 & 3.43 & 0.0402 & 0.1378 \\
\hline 8 & 4.39 & 3.59 & 0.0418 & 0.1500 \\
\hline 9 & 4.26 & 3.53 & 0.0406 & 0.1433 \\
\hline 10 & 3.99 & 3.50 & 0.0380 & 0.1330 \\
\hline 11 & 4.07 & 3.59 & 0.0388 & 0.1392 \\
\hline 12 & 4.03 & 3.53 & 0.0384 & 0.1356 \\
\hline 13 & 4.34 & 3.53 & 0.0414 & 0.1461 \\
\hline
\end{tabular}




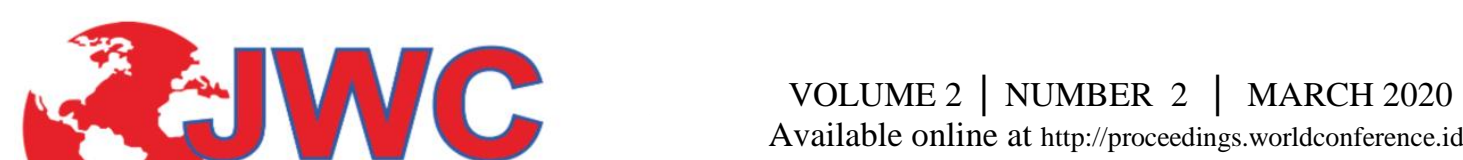

Available online at http://proceedings.worldconference.id. ISSN: 2656-1174 (online)

\begin{tabular}{|c|c|c|c|c|}
\hline Attribute & Interest Score & $\begin{array}{c}\text { Performance } \\
\text { Score }\end{array}$ & $\begin{array}{c}\text { Weight } \\
\text { Factor }\end{array}$ & $\begin{array}{c}\text { Weight } \\
\text { Score }\end{array}$ \\
\hline 14 & 4.14 & 3.44 & 0.0395 & 0.1360 \\
\hline 15 & 4.26 & 3.27 & 0.0406 & 0.1328 \\
\hline 16 & 4.27 & 3.54 & 0.0407 & 0.1443 \\
\hline 17 & 4.30 & 3.81 & 0.0410 & 0.1564 \\
\hline 18 & 4.17 & 3.57 & 0.0398 & 0.1421 \\
\hline 19 & 4.16 & 3.63 & 0.0396 & 0.1439 \\
\hline 20 & 3.97 & 3.57 & 0.0379 & 0.1353 \\
\hline 21 & 4.20 & 3.56 & 0.0401 & 0.1425 \\
\hline 22 & 4.14 & 3.53 & 0.0395 & 0.1394 \\
\hline 23 & 4.11 & 3.46 & 0.0392 & 0.1356 \\
\hline 24 & 4.14 & 3.54 & 0.0395 & 0.1400 \\
\hline 25 & 4.16 & 3.44 & 0.0396 & 0.1365 \\
\hline Rata-Rata & 4.19 & 3.52 & 0.0345 & 0.1215 \\
\hline Jumlah & 104.86 & & & 3.52 \\
\hline & & & CSI & $\mathbf{7 0 . 4 6 \%}$ \\
\hline
\end{tabular}

Source: Data in research, 2020

The results of the analysis of the level of service performance and the level of interest of the public transport services in the area of Dukuh Atas generate customer satisfaction index by $70.46 \%$. This value is in the range of values between 0.66 to 0.80 in which the CSI criteria in this range are satisfied. This means that the general public transport passengers in Region Dukuh Atas satisfied with the services and facilities are perceived.

3.6 The Chi-Square test

From the results of the Chi-Square test with a significance level of $25 \%$, it showed that the level of education and sex with customer satisfaction showed a p-value $<0: 25$, which means that the level of education and gender had a significant association with the degree of satisfaction. This relationship can be caused by some of the following:

a) Based on the results of primary data processing shows that most of the passengers of public transport in the Dukuh Atas area education high enough that from high school to S2 / S3 so that it has a critical assessment of what is expected and received, and thus the level of education has a correlation with the level of customer satisfaction,

b) Educational variables associated with the type of work, where if you have a high enough level so obtained will work better anyway. When viewed from primary data, the majority have jobs as private employees or civil servants / BUMN employees who need to be punctual in their travels. As it relates to working hours set by the company work. Punctuality is one of the important variables that affect the level of customer satisfaction.

\section{Conclusion}

From the results, the following conclusions:

1. The results of the CSI (Customer Satisfaction Index) note that CSI scores of 0,7046 or $70.46 \%$ which is where the value is in the range of values from 0.66 to 0.80 , which means consumers satisfied with the performance of services and facilities provided by public transport in the Dukuh Atas area.

2. There are 6 attributes of quality of service deemed most important by consumers of public transportation in the Dukuh Atas area, among others, the following: the convenience of purchasing tickets for public transportation modes, the ability of officers to direct passengers to their destination, the integration of a means of payment for a variety of transportation, ease in reaching out to the public transport, access to information transport services, the availability of transfer between access in public transport. 


\section{References}

[1] Asri, D., \& Hidayat, B. (2005). Transportation Current Issues in Jakarta and Its Impacts on the Environment. Proceedings of the Eastern Asia Society for Transportation Studies, Vol. 5, pp. 1792-1798.

[2] Tamin, OZ (2000). Transportation Planning and Modeling. Bandung: Bandung Institute of Technology Publisher.

[3] Saliara, K. (2014). Public transport integration: the case study of Thessaloniki, Greece. Transportation Research Procedia, 4, 535-552.

[4] Brandt, D.R. (2000). An "Outside-In" Approach to Determining Customer Driven Priorities for Improvement and Innovation. White Paper Series, Volume 2-2000

\section{Biography}

Andri Irfan Rifai is a lecturer at Mercu Buana University and head of the bachelor program in civil engineering in Batam Internasional University. He earned Bachelor in civil engineering in Sebelas Maret University, Master in civil engineering from University of Indonesia and $\mathrm{PhD}$ in Transportation Engineering from University of Indonesia - Universidade do Minho, Portugal. Dr. Andri Irfan is also works in Indonesia Ministry of Public Works and Housing as Project Manager at Rehabilitation and Reconstruction project in Palu Disaster Area.

Fachrul Arifin is a student of the Faculty of Civil Engineering at Mercu Buana University in 2018 and successfully completed her undergraduate education in February 2020. Mr. Fachrul Arifin is also works in a national contracting company as a quantity surveyor in a building project, with Diploma degree in civil engineering from State Polytechnic of Jakarta. 